\title{
Frequency of Fast Food Consumption: Effects on the Nutritional Status of Groups Aged 12-22 Years
}

\author{
Magda M. Shabayek \& Sanaa I. Saleh \\ Nutrition Dept., Central Lab for Food and Feed, Agric. Research, Center, Alexandria.
}

\begin{abstract}
Fast food consumption has increased greatly particularly among youth. The attraction of eating fast food items makes the youth gain weight and badly affects their health. To study the effect of frequency fast food consumption, 868 subjects (males and females) aged 12-22 years were selected randomly from clubs and youth centers in Alexandria city. Socio-demographic characteristics, frequency and attitude toward fast food consumed, weight, height and body mass index (BMI) were recorded. Dietary intake was estimated using 24 hours recall for 3 consecutive days. It was found that consumption of fast food was prevalent between both genders. Frequency of consumption of fast food showed that $38.7 \%$ of subjects eat fast food frequently (group1) and $61.3 \%$ of them eat fast food less frequently (group2). Proportion of subjects with BMI greater than $85^{\text {th }}$ percentile was significantly higher among group $1(36.9 \%)$ than group $2(28.9 \%)$ indicating a risk of overweight and obesity of subjects, who eat fast food frequently compared with those who eat fast food less frequently, consumed higher intake of energy, protein, fat and carbohydrate. Mean energy intake of males and females in group1 and group2 covered $(85.3 \%, 78.1 \%)$ and $(92.3 \%, 84.1 \%)$, respectively of RDA, while protein intake exceeded the recommendation for both groups. Television advertisements have a significant influence on fast food consumption. Only $22 \%$ of group 1 and $31.2 \%$ of group 2 believed that fast food can cause disease cases, while $41.7 \%$ of group 1 and $43.2 \%$ of group 2 believed that consumption of fast food is harmless. Animal protein was consumed in high proportion of subjects eat fast food frequently, while consumption of plant protein was high among those eat fast food less frequently. Public health measures should be aimed at limiting the amount and frequency of fast food consumption. This could include nutritional education campaigns, regulation of fast food advertising, getting rid of fast food restaurants in schools, and increasing healthy food vendings in youth centers, clubs, schools, and education foundations.
\end{abstract}

Keywords: adolescents, fast food, energy intake, obesity, nutritional status.

\section{INTRODUCTION}

Eating outdoor is an ancient practice. In Egypt around 512 B.C. a restaurant offered a single dish of wild foul, cereals and onions. Of course, restaurants have changed since 2500 years ago. Today, there are over 500,000 fast food restaurants worldwide, which are fast, fun, inexpensive and can be found almost everywhere, even in some schools (FAQ, 2006).

Fast food is a food, which is prepared and served quickly at outlets called fast-food restaurants. Fast-food outlets are take-away or take-out providers, in which customers can eat the food inside the premises. Fast foods include fish and chips, sandwiches, hamburgers, fried chicken, French fries, chicken nuggets and pizza (Wikipedia, 2006).

Fast food pervades virtually all segments of society including local communities, public schools and hospitals (Zive et al., 2002).This trend seems to have been driven by massive advertising and marketing campaigns aimed at children and their parents (Nestle, 2002).
The number of teenagers eating more fast food is increasing since the 1970s. Since this overeating and obesity have also been on the rise. This is due to huge portion sizes, high calorie content, refined flour, added sugar, high fat content and low levels of dietary fiber (Ebbeling et al., 2004). Unsafe dieting practices among youth not only cause nutritional deficiencies, but also physical and psychological problems. Previous studies demonstrate that consumption of fast food is directly related to total energy intake and adversely related to diet quality (French et al., 2001, Shanthy et al., 2004). Some other studies indicate the presence of a direct relation between fast food and body weight (Binkley et al., 2000, Pereira et al., 2003).

Fast food is ubiquitously available and widely marketed to adolescents (Story et al., 2002). Accordingly, the objective of the present study was to evaluate the effect of frequency of fast food consumption on the nutrition status of adolescent and youth groups. 


\section{MATERIALS AND METHODS}

A random sample of 868 adolescents and youths aged 12-22 years, from clubs and youth centers in Alexandria city were randomly selected from July to September 2005. Data about fast food consumption were gathered by a questionnaire concerning frequency of food consumed away from home to identify subjects who frequently eat fast food and from others who eat less frequently such foods. Each subject was interviewed and asked about demographic and social situation (Fahmy \& ElSherbini, 1983), daily pocket money, habit and attitude toward fast food consumed. Nutrition status was assessed using mean daily dietary intake and anthropometric assessment. Dietary data were obtained using 24 hours recall method for three random consecutive days including a weekend. Weight and height were measured using standard methods to determine body mass index (BMI) which was derived from weight $\mathrm{kg} /$ height $^{2} \mathrm{~m}$ (Jellife, 1996). The nutritional status of adolescents was assessed using the obtained BMI and compared with the standard BMI/age established by (WHO, 1991), as follows: $<5^{\text {th }}$ percentile of the normal distribution indicated underweight or thinness $5^{\text {th }}$ $85^{\text {th }}$ percentile indicated normal weight, $85^{\text {th }}$ $95^{\text {th }}$ percentile indicated overweight and $\geq 95^{\text {th }}$ percentile for obese.

The centers for disease control and prevention defines childhood overweight as a BMI exceeding sex-and age-specific $95^{\text {th }}$ percentiles and at risk of overweight as a BMI between the $85^{\text {th }}$ and $95^{\text {th }}$ percentiles using the 2000 growth charts (Kuczmarski et al., 2000).

Nutritive values of diet were obtained using food composition Tables of Nutrition Institute (1996). Nutrition adequacy of diet was calculated by reference to the recommended daily allowances "RDA" (National Research Council, 1989).

Data were statistically analyzed using personal computers. Student t-test was used for comparison of means of a quantitative data and the chi-square test between two or more groups. Subjects were divided, according to frequency of fast food consumption, into two groups:

Group (1); subjects eat fast food frequently and group (2); subjects eat fast food less frequently.

\section{RESULTS AND DISCUSSION}

\section{Sample characteristics}

Nowadays, children and teenagers eat more meals away from home than they did twenty years ago. According to USDA (2000), fully $72 \%$ of teenage males and $64 \%$ of teenage females ate away from home on any given day. Meals eaten away from home contributed to approximately one third of these teens' daily energy and macronutrient intake.

Data in Table (1) show that the frequency of consuming food away from home was prevalent between both genders under study. The results presented in Table (1) show that $38.7 \%$ of subjects (39.6\% males, $37.9 \%$ females) eat fast food frequently (group1) while 61.3\% (60.4\% males, $62.1 \%$ females) of them eat fast food less frequently (group2). The age averages of group1 and group2 subjects were 17.1 \pm 3.1 years and $16.4 \pm 2.9$ years, respectively and the difference between the two groups was statistically highly significant $(\mathrm{t}=3.5, \mathrm{P}<0.01)$. It could be mentioned that all the subjects interviewed were students who received intermediate and high education level. Student teenagers spend long time away from home and hence are obliged to consume foods purchased from fast food restaurants. This agrees with the fact that adolescent and teenagers prefer to purchase fast food with their own money (Nestle, 2002).

Subjects eat fast food frequently and those eat such food less frequently did not differ in the socioeconomic background except in the regard of their father's and mother's education which was higher among those eat fast food less frequently. The difference was small between the two groups (1 and 2) in all other respects under comparison. As shown in Table (1), large differences were found between the parent's educations in both groups, on one hand about half $51.9 \%$ and $44 \%$ of both parents in group 2 had high education compared to $42.9 \%$ and $33.9 \%$ in group 1 with a highly significant difference between them $\left(X^{2}=6.7\right.$ and $X^{2}=$ $12.2, \mathrm{P}<0.01)$. On the other hand, there was no significant difference between group1 $(69 \%)$ and group2 (64.3\%) concerning employment of mothers. In the present study, $46.4 \%$ of subjects of group 1 and $47 \%$ of group2 were of high economic level comparing with $30.4 \%$ and $35 \%$ of them belonged to low and very low level, respectively. 
Data in Table (1) indicate that the mean daily pocket money of subjects of group 1 $(2.0 \pm 1.8$ L.E) was significantly higher $(\mathrm{t}=3$, $\mathrm{P}<0.01)$ than that of group 2, which was $1.7 \pm 1.4$ L.E. It could be noticed that pocket money of $19 \%$ in group1 and $28.6 \%$ in group 2 was less than one L.E. Data indicated that pocket money of the highest proportion of subjects (42\% in group 1 and $35.4 \%$ in group 2$)$ was one L.E. These results are in general agreement with data reported by Osman (1997). The aforementioned results proved that daily pocket money of subjects (males and females) plays a major role in determining the frequency and type of fast food consumption, as with one L.E it is possible to purchase some plant protein fast food like stewed beans and bean burger (foul and falafel) due to their low price.

\section{Anthropometric characteristics.}

In 1989 (fast food fare), a published statement warned that a lifetime of fast food consumption may place children at increased risk for obesity. However, until recently, the poten- tially adverse effects of fast food in youth have received limited attention in the medical literature (Shanty et al., 2004). Some nutrition professionals argue that fast food is contributing to the obesity epidemic (St Onge et al., 2003), whereas others support industry claims that fast food can be part of a healthful diet (FreelandGraves \& Nitzke, 2002).

From the results presented in Table (2), it could be observed that the mean weight and mean height of males were significantly higher than those of females in the two groups. A highly significant difference $(\mathrm{t}=2.9, \mathrm{P}<0.01)$ in the mean weight and only a significant difference $(2.3, \mathrm{P}<0.05)$ in BMI were found between both groups. It could be mentioned that there was no significant difference in height between the two groups under study. The proportion of subjects with a BMI greater than $85^{\text {th }}$ percentile was significantly higher $(\mathrm{t}=4.8, \mathrm{P}<0.01)$ among group $1(36.9 \%)$ than among group $2(28.9 \%)$ indicating a risk of overweight and obesity. These findings exceeded the values reported

\section{Table 1: Compared characteristics of the selected subjects}

\begin{tabular}{|c|c|c|c|c|c|}
\hline \multirow{2}{*}{ Characteristics } & \multicolumn{2}{|c|}{ Group (1) eat frequently } & \multicolumn{2}{|c|}{ Group (2) eat less frequently } & \multirow{2}{*}{\begin{tabular}{|c|} 
Test of \\
Significance
\end{tabular}} \\
\hline & No. & $\%$ & No. & $\%$ & \\
\hline $\begin{array}{l}\text { Total sample } \\
\text { Gender: } \\
\text { Male } \\
\text { Female }\end{array}$ & $\begin{array}{l}336 \\
164 \\
172 \\
\end{array}$ & $\begin{array}{l}38.7 \\
39.6 \\
37.9\end{array}$ & $\begin{array}{l}532 \\
250 \\
282\end{array}$ & $\begin{array}{l}61.3 \\
60.4 \\
62.1\end{array}$ & \\
\hline $\begin{array}{c}\text { Age (years) } \\
12-<15 \\
15-<19 \\
19-22 \\
\text { Mean } \pm \text { S.D }\end{array}$ & $\begin{array}{l}104 \\
96 \\
136 \\
17.1 \pm 3.1\end{array}$ & $\begin{array}{l}30.9 \\
28.6 \\
40.5\end{array}$ & $\begin{array}{l}180 \\
218 \\
134 \\
16.4 \pm 2.9\end{array}$ & $\begin{array}{l}33.8 \\
41.0 \\
25.2\end{array}$ & $\mathrm{t}=3.5 * *$ \\
\hline $\begin{array}{l}\text { Father education } \\
<\text { primary } \\
\text { Intermediate } \\
\text { High }\end{array}$ & $\begin{array}{l}76 \\
116 \\
144 \\
\end{array}$ & $\begin{array}{l}22.6 \\
34.5 \\
42.9 \\
\end{array}$ & $\begin{array}{l}98 \\
158 \\
276 \\
\end{array}$ & $\begin{array}{l}18.4 \\
29.7 \\
51.9 \\
\end{array}$ & $\mathrm{X}^{2}=6.7 * *$ \\
\hline $\begin{array}{l}\text { Mother education } \\
<\text { primary } \\
\text { Intermediate } \\
\text { High }\end{array}$ & $\begin{array}{l}92 \\
130 \\
114\end{array}$ & $\begin{array}{l}27.4 \\
38.7 \\
33.9 \\
\end{array}$ & $\begin{array}{l}100 \\
198 \\
234\end{array}$ & $\begin{array}{l}18.8 \\
37.2 \\
44.0\end{array}$ & $\mathrm{X}^{2}=12.2^{* *}$ \\
\hline $\begin{array}{l}\text { Mother occupation } \\
\text { Employed } \\
\text { Unemployed }\end{array}$ & $\begin{array}{l}104 \\
232\end{array}$ & $\begin{array}{l}31.0 \\
69.0\end{array}$ & $\begin{array}{l}190 \\
342\end{array}$ & $\begin{array}{l}35.7 \\
64.3\end{array}$ & $X^{2}=2.0$ N.S. \\
\hline $\begin{array}{l}\text { Socioeconomic level } \\
\text { High } \\
\text { Middle } \\
\text { Low / very low } \\
\end{array}$ & $\begin{array}{l}156 \\
78 \\
102 \\
\end{array}$ & $\begin{array}{l}46.4 \\
23.2 \\
30.4 \\
\end{array}$ & $\begin{array}{l}250 \\
96 \\
186 \\
\end{array}$ & $\begin{array}{l}47.0 \\
18.0 \\
35.0 \\
\end{array}$ & $X^{2}=4.1$ N.S. \\
\hline \begin{tabular}{|l} 
Pocket money (L.E) \\
$<1$ \\
$1-$ \\
$2-$ \\
$3>$ \\
Mean \pm S.D \\
\end{tabular} & $\begin{array}{l}64 \\
141 \\
71 \\
60 \\
2.0 \pm 1.8\end{array}$ & $\begin{array}{l}19.0 \\
42.0 \\
21.1 \\
17.9\end{array}$ & $\begin{array}{l}152 \\
188 \\
104 \\
88 \\
1.7 \pm 1.4\end{array}$ & $\begin{array}{l}28.6 \\
35.4 \\
19.5 \\
16.5\end{array}$ & $\begin{array}{l}\mathrm{X}^{2}=10.4^{* *} \\
\mathrm{t}=3.0 * *\end{array}$ \\
\hline $\begin{array}{l}2^{2}=\text { Chi-square test } \\
=\text { Student } \mathrm{t} \text {-test }\end{array}$ & $\mathrm{N}$ & $\begin{array}{l}05 \\
\text { t significa }\end{array}$ & & $\mathrm{P}<0.01$ & \\
\hline
\end{tabular}


Table 2: Anthropometric characteristics of the selected subjects

\begin{tabular}{|c|c|c|c|c|c|c|c|}
\hline \multirow{2}{*}{ Characteristics } & \multicolumn{3}{|c|}{ Group (1) eat frequently } & \multicolumn{3}{|c|}{ Group (2) eat less frequently } & \multirow{2}{*}{$\begin{array}{c}\text { Test of } \\
\text { Significance }\end{array}$} \\
\hline & Males & Females & Total & Males & Females & Total & \\
\hline \multicolumn{8}{|l|}{$\overline{\text { Weight }(\mathrm{kg})}$} \\
\hline Mean & 69.3 & 61.6 & 65.4 & 65.7 & 59.1 & 62.2 & \\
\hline \pm S.D. & 16.7 & 13.7 & 15.7 & 17.3 & 13.1 & 15.6 & $\mathrm{t}=2.9 * *$ \\
\hline \multicolumn{8}{|l|}{ Height (cm) } \\
\hline Mean & 172.0 & 159.7 & 165.7 & 169.7 & 159.7 & 164.3 & \\
\hline \pm S.D. & 11.1 & 11.4 & 12.8 & 10.1 & 6.7 & 9.8 & $\mathrm{t}=1.8 \mathrm{~N} . \mathrm{S}$ \\
\hline \multicolumn{8}{|l|}{$\overline{\mathrm{BMI}}$} \\
\hline Mean & 23.3 & 23.8 & 23.6 & 22.7 & 23.1 & 22.9 & \\
\hline \pm S.D. & 4.6 & 4.4 & 4.5 & 5.3 & 4.7 & 5.0 & $\mathrm{t}=2.3 * *$ \\
\hline \multicolumn{8}{|l|}{$\%$ under weight } \\
\hline$<5^{\text {th }}$ percentage & 7.3 & -- & 3.6 & 5.6 & $\begin{array}{l}3.5 \\
\mathrm{t}=7.5 * *\end{array}$ & 4.5 & $\mathrm{t}=0.0 \mathrm{~N} . \mathrm{S}$ \\
\hline \multicolumn{8}{|l|}{$\%$ normal } \\
\hline$<85^{\text {th }}$ percentile & 54.9 & $\begin{array}{l}64.0 \\
t=0.7 \mathrm{~N} . \mathrm{S}\end{array}$ & 59.5 & 67.2 & $\begin{array}{l}66.0 \\
t=1.0 \mathrm{NS}\end{array}$ & 66.6 & $\mathrm{t}=3.0 * *$ \\
\hline \multicolumn{8}{|c|}{ \% overweight \& obese } \\
\hline$>85^{\text {th }}$ percentile & 37.8 & $\begin{array}{c}36.0 \\
\mathrm{t}=1.5 \text { N.S. }\end{array}$ & 36.9 & 27.2 & $\begin{array}{l}30.5 \\
\mathrm{t}=2.33 * *\end{array}$ & 28.9 & $\mathrm{t}=4.8^{* *}$ \\
\hline
\end{tabular}

$\mathrm{t}=$ Student $\mathrm{t}$-test

N.S. $=$ Not significant

$* *=\mathrm{P}<0.01$

among Irish teenagers in which only between $1.1 \%$ and $8.2 \%$ of subjects indicating a risk of overweight (Hurson \& Corish, 1997). Specifically, males eat fast food frequently $(37.8 \%)$ and females $(36 \%)$ were found to have the highest prevalence of overweight and obesity with no significant difference compared with group eat less frequently in which only significant difference $(\mathrm{t}=2.3, \mathrm{P}<0.05)$ was observed between males $(27.2 \%)$ and females $(30.5 \%)$.

Researchers found that all teenagers tend to overeat when served a typical extra-large fast food meal, but normal-weight teenagers were more likely than overweight teens to make up for the overindulgence by eating less later on . Overweight kids tend to be less able to compensate for the extra calories in a fast food meal (Ebbeling et al., 2004).

\section{Nutrient intake}

Subjects eat fast food frequently consumed high energy intake than subjects eat it less frequently as shown in Table (3). It is apparent that the mean daily energy intake of females in group1 (2031.4 kcal) and group2 (1849.7 kcal) was lower than that of males $(2394.8 \mathrm{kcal}$ and $2181.7 \mathrm{kcal}$ ) in both groups, respectively. Females in groupland group 2 covered $92.3 \%$ and $84.1 \%$ of energy intake while males in group1satisfying $85.3 \%$ and in group2 only $78.1 \%$, respectively. Protein contributed about $16 \%$ of the energy intake; fat $26-28 \%$ and carbohydrate $61-62 \%$, only minor differences were noted between both genders in the two groups under study. The mean daily protein intake of males and females exceeded the recommended daily intake for both groups. On the other hand, males generally eat high intake of protein, fat and carbohydrate than females in both groups. In comparison with values reported in similar studies in United States (Ebbeling et al., 2004 \& Shanthy et al., 2004), the values observed in the present study were higher. Fast food may increase energy intake, thus promoting a positive energy balance and increasing risk of obesity. This is due to the composition of typical fast foods as cheeseburgers, French fries and other foods popular among youth (Subar et al., 1998).

Bell and Parnell (1996) reported that children who obtain most of their nutrients from meat, bakery products, dairy products, fat, sweets, snacks and fast food and consumed less fruits and vegetables are subjected to heart diseases and other diseases later in their life.

French et al. (2001) found that fast food consumption to be associated with higher total energy intake and poorer diet quality among adolescents in a Metropolitan area of Minnesota. Shanthy et al. (2004) found that adolescent girls who ate fast food consumed more total energy than those who ate fast food less frequently.

The prevalence of obesity in children has increased threefold or more during the last 3 decades raising serious public health concerns (National Center for Health Statistics, 2003). A number of environmental factors undoubtedly have contributed to this epidemic (Shanthy et al., 2004). Furthermore, fast food is served in increasingly large portion sizes, which had been linked to voluntary energy intake (Rolls et al., 2002). 
Table 3: Mean \pm S.E of the daily intake and adequacy of the main three nutrients

\begin{tabular}{|l|l|l|l|l|}
\hline \multirow{2}{*}{ Nutrients } & \multicolumn{2}{c|}{ Group (1) eat frequently } & \multicolumn{2}{c|}{ Group (2) eat less frequently } \\
\cline { 2 - 5 } & \multicolumn{1}{|c|}{ Males } & \multicolumn{1}{c|}{ Females } & \multicolumn{1}{c|}{ Males } & \multicolumn{1}{c|}{ Females } \\
\hline Total energy (kcal) & $2394.8 \pm 51.9$ & $2031.4 \pm 88.8$ & $2181.7 \pm 40.3$ & $1849.7 \pm 55.1$ \\
\% of adequacy & 85.3 & 92.3 & 78.1 & 84.1 \\
\hline Protein $(\mathrm{g})$ & $95.7 \pm 2.3$ & $80.6 \pm 2.4$ & $85.8 \pm 1.5$ & $74.4 \pm 1.5$ \\
\% of energy & 16.0 & 15.9 & 15.7 & 16.1 \\
\% of adequacy & 176.6 & 176.9 & 161.0 & 164.7 \\
\hline Fat (g) & $74.9 \pm 2.1$ & $63.2 \pm 1.9$ & $64.2 \pm 1.5$ & $56.3 \pm 1.0$ \\
\% of energy & 28.11 & 28.0 & 26.5 & 27.4 \\
\hline Carbohydrate $(\mathrm{g})$ & $359.5 \pm 9.0$ & $311.3 \pm 18.4$ & $340.5 \pm 7.1$ & $280.6 \pm 11.5$ \\
\% of energy & 60 & 61.3 & 62.4 & 60.7 \\
\hline
\end{tabular}

S.E. $=$ Standard error of the mean

\section{Habit and attitude toward fast food}

It has been argued that adolescence is a period of opposition against everything even food habit (Anderson et al., 1994).

Regarding habit and attitude toward fast food eaten by both genders as presented in Table (4), a highly significant difference $(\mathrm{P}<0.01)$ could be traced between subjects eat fast food frequently and those eat less frequently. The results show that television advertisements have a significant influence on fast food consumption, $44.0-48.5 \%$ of the subjects eat fast food get their knowledge about fast food from television. Subjects were found to spend a lot of time watching television, which attract and maintain their attention to the advertised products making such products highly desirable. This agrees with the fact that children and adolescents spend a great deal of time watching television and hence being exposed to advertising for food products. Advertise is believed by manufacturer and marketers to be highly effective in selling particular products and have been shown in experimental studies to have an influence on food choice of children and adolescents (Adler et al., 1997).

The results shown in Table (4) indicate that summer is the most season through which consumption of fast food increased among subjects eat frequently $(41.1 \%)$ and those eat less frequently $(42.1 \%)$ with a highly significant difference between them $\left(\mathrm{X}^{2}=13.04, \mathrm{P}<0.01\right)$. This is due to the fact that youth spend their summer holiday in clubs and beside beaches. They spend long time outdoors and hence have a chance for consuming additional meals outside homes. This was in agreement with the fact that outside home in clubs, restaurants, school cafeteria or street were favorable places for eating fast food among the subjects under study, it was more common among subjects eat frequently (81.5\%) than ones eat less frequently (76.7\%), and also those places were suitable to meet their friends.

As regard the reason for eating fast food, the results in Table (4) show that more than half of subjects eat fast food as a sort of change. This reason was slightly lower among subjects eat frequently $(51.8 \%)$ than subjects eat less frequently $(52.6 \%)$. It is worth to mention that work of mothers was the least reason for eating fast food among group $1(4.2 \%)$ and group 2 $(6.8 \%)$. Concerning subjects knowledge about the nutritive value of fast food, there was a highly significant difference between both groups $\left(\mathrm{X}^{2}=14.12, \mathrm{P}<0.01\right)$. The results reveal that $24.4 \%$ of subjects eat frequently and $15 \%$ of subjects eat less frequently assumed that fast food have a good nutritive value, while $38.1 \%$ and $36.8 \%$ presumed that nutritive value is moderate. On the other hand, $14.9 \%$ of group 1 considered fast food of poor nutritive value compared with $20.7 \%$ of group 2 .

Regarding beliefs about health effect of fast food, there was a highly significant difference between both groups $\left(\mathrm{X}^{2}=14.3, \mathrm{P}<0.01\right)$, only $22 \%$ of subjects eat fast food frequently and $31.2 \%$ of those eat less frequently believe that fast food can cause disease. In contrast, $41.7 \%$ of subjects eat fast food frequently and $43.2 \%$ of subjects eat less frequently believe that fast foods are harmless. It was also noted that $36.3 \%$ of subjects of group 1 and $25.6 \%$ of group2 did not know if fast food can cause any health hazards or not.

A recent survey directly questioned young people about their most important consideration when deciding what to eat; taste and quality were found to be primary, while cost and health concerns were of secondary importance (Adler et al., 1997). 
Table 4: Distribution of subjects according to habit and attitude toward fast food

\begin{tabular}{|c|c|c|c|c|c|}
\hline \multirow[t]{2}{*}{ Items } & \multicolumn{2}{|c|}{$\begin{array}{c}\text { Group (1) eat frequently } \\
n=336\end{array}$} & \multicolumn{2}{|c|}{$\begin{array}{c}\text { Group (2) eat less frequently } \\
n=532\end{array}$} & \multirow{2}{*}{$\begin{array}{c}\text { Test of } \\
\text { significance }\end{array}$} \\
\hline & No. & $\%$ & No. & $\%$ & \\
\hline \multicolumn{6}{|c|}{ Sources of information about fast food } \\
\hline Families & 44 & 13.1 & 60 & 11.3 & \\
\hline Friends & 80 & 23.8 & 134 & 25.2 & \\
\hline Television & 148 & 44.0 & 258 & 48.5 & \\
\hline Television \& Friends & 64 & 19.1 & 80 & 15.0 & $\mathrm{X}^{2}=3.5$ N.S \\
\hline \multicolumn{6}{|l|}{ Season of increased eaten fast food } \\
\hline Summer & 138 & 41.1 & 224 & 42.1 & \\
\hline Winter & 68 & 20.2 & 156 & 29.3 & \\
\hline All year round & 130 & 38.7 & 152 & 28.6 & $\mathrm{X}^{2}=13.04 * *$ \\
\hline \multicolumn{6}{|l|}{ Place of eating fast food } \\
\hline Inside home & 62 & 18.5 & 124 & 23.3 & \\
\hline Outside home & 274 & 81.5 & 408 & 76.7 & $\mathrm{X}^{2}=2.9$ N.S \\
\hline \multicolumn{6}{|l|}{ Reasons for eating fast food } \\
\hline Work of mother & 14 & 4.2 & 36 & 6.8 & \\
\hline Sort of change & 174 & 51.8 & 280 & 52.6 & \\
\hline During school and private lesson & 148 & 44.0 & 216 & 40.6 & $\mathrm{X}^{2}=3.01 \mathrm{~N} . \mathrm{S}$ \\
\hline \multicolumn{6}{|c|}{ Beliefs about health effect of fast food } \\
\hline Cause disease & 74 & 22.0 & 166 & 31.2 & \\
\hline Harmless & 140 & 41.7 & 230 & 43.2 & \\
\hline Do not know & 122 & 36.3 & 136 & 25.6 & $\mathrm{X}^{2}=14.29 * *$ \\
\hline \multicolumn{6}{|l|}{ Nutritive value of fast food } \\
\hline Good & 82 & 24.4 & 80 & 15.0 & \\
\hline Moderate & 128 & 38.1 & 196 & 36.8 & \\
\hline Poor & 50 & 14.9 & 110 & 20.7 & \\
\hline Do not know & 76 & 22.6 & 146 & 27.5 & $\mathrm{X}^{2}=14.12^{* *}$ \\
\hline \multicolumn{6}{|l|}{ Taste of fast food } \\
\hline Excellent & 148 & 44.0 & 218 & 41.0 & \\
\hline Favourable & 186 & 55.4 & 300 & 56.4 & \\
\hline $\mathrm{Bad}$ & 2 & 0.6 & 14 & 2.6 & $\mathrm{X}^{2}=5.2$ N.S \\
\hline \multicolumn{6}{|l|}{ Price of fast food } \\
\hline High & 62 & 18.4 & 118 & 22.2 & \\
\hline Moderate & 272 & 81.0 & 386 & 72.5 & \\
\hline Low & 2 & 0.6 & 28 & 5.3 & $\mathrm{X}^{2}=16.1^{* *}$ \\
\hline
\end{tabular}

$\mathrm{X}^{2}=$ Chi-square test $\quad * *=\mathrm{P}<0.01$

The results shown in Table (4) indicate that $55.4 \%$ and $56.4 \%$ of subjects of group 1 and group2 considered the taste of fast food favorable, while $44 \%$ and $41 \%$ of them noted that the taste was excellent. Also, $81 \%$ of subjects eat frequently and $72.5 \%$ of those eat less frequently considered that the price of fast food is moderate comparing with only $0.6 \%$ of group 1 and $5.3 \%$ of group 2 who indicated that the price was low.

\section{Types of fast food consumed}

Concerning order of popularity of fast food consumed, the data in Table (5) show
N.S. = Not significant

that the consumption of animal protein was high (89.3\%) among group eat frequently followed by plant protein $(71.4 \%)$, bakery products $(46.4 \%)$ and the least was French fries (38.7\%). While among group eat fast food less frequently, plant protein was high (91.7\%) followed by $29.3 \%$ and $21.4 \%$ for animal protein and French fries, respectively, while consumption of bakery products was tailing behind being $15.8 \%$ only.

High daily pocket money of subjects eat fast food frequently is linked with the high consumption of animal proteins which cost high

Table 5: Distribution of subjects according to types of fast food eaten

\begin{tabular}{|l|c|c|c|c|}
\hline \multirow{2}{*}{ Nutrients } & \multicolumn{2}{|c|}{ Group (1) eat frequently } & \multicolumn{2}{c|}{ Group (2) eat less frequently } \\
\cline { 2 - 5 } & No & \% & No & \% \\
\hline French fries & 130 & 38.7 & 114 & 21.4 \\
Bakery products & 156 & 46.4 & 84 & 15.8 \\
Plant protein & 240 & 71.4 & 488 & 91.7 \\
Animal protein & 300 & 89.3 & 156 & 29.3 \\
\hline
\end{tabular}


price than plant proteins. On the other hand, subjects eat fast food less frequently were more likely to consume plant proteins because of its relatively cheap price. It is noticed that within animal proteins the most common types consumed were hamburger, liver, sheish tawook, kofta, fried chicken and shawerma. Beans (foul and falafel) were the favorite and most popular types of plant proteins consumed followed by koshary. While variety of bakery products were pies, pizza, croissant and cake. This finding is in accordance with those found by Osman (1997). The ubiquities of fast food establiments may account for the high level of consumption of those foods. Youth of higher socioeconomic status may have more discretionary money and consequently greater access to fast food.

Based on the previously results, it could be concluded that with the increase of fast food establishments, consumption of fast food among youth has increased. Teens' growing independence and busy schedules often mean fewer meals with the family and more food purchased from fast food restaurants and school cafeteria .These are the most frequent sources for outside food for males and females and offer a brightly coloured environment and a place to meet friends. Food eaten away from home may be less nutritious than home meals, generally poor, lacking essential nutrients, high in fat, salt and sugar. Increase in the family's income which reflect the increase daily pocket money of youth, socio cultural factors and the mass media especially televised food advertisement have played an important role in increasing the consumption of fast food. Fast food consumption among youth affects diet quality in ways that increase risk for obesity. Although the causes of obesity are multifaceted, public health measures to limit fast food consumption in children and adolescent may be warranted. Such measures could include nutrition education campaigns, legislation to regulate marketing of fast food to children, and elimination of fast food from schools.

\section{REFERENCES}

Adler, R., Fried lander, B. \& Tesser, O. 1997. Research on the effect of TV advertising on children: A review of the literature and recommendation for future research. Washington DC. USA. Government printing office.

Anderson, A.S., Macintyre, S. \& West P. 1994. Dietary patterns among adolescents in the west of Scotland. Br J Nutr. 71:11122.
Bell, A.C. \& Parnell, W.R. 1996. Nutrient intakes of tongam and tokelanan children living in New Zealand. New Zealand Medical Journal. 109:435-43.

Binkley, J.K., Eales, J. \& Jekanowski, M. 2000. The relation between dietary change and rising US obesity. Int J Obes Relat Metab Disord. 24:1032-1039.

Ebbeling, C.B., Sinclair, K.B., Pereira, M.A., Lago, E.G., Feldman, H.A. \& Ludwig, D.S. 2004. Compensation for energy intake from fast food among overweight and lean adolescents. JAMA. 291(23): 2828-2833.

Fahmy, S.I. \& El-Sherbini, A.F. 1983. Determining simple parameters for social classifications for health research. Bull High Inst Public Health. 13 (5): 95-107.

FAQ. 2006. FAQ library oracle education foundation. http://Library, thinkquest, org.

Fast-food fare: consumer guidelines. 1989. N Engl J Med. 321:752-756.

Freeland-Graves, J. \& Nitzke, S. 2002. Position of the American Dietetic Association: total diet approach to communicating food and nutrition information. $\mathrm{J}$ Am Diet Assoc.102:100-108.

French, S.A., Story, M., Neumark-Sztainer, D., Fulkerson, J.A. \& Hannan, P. 2001. Fast food restaurant use among adolescents: associations with nutrient intake, food choices and behavioral and psychosocial variables. Int $\mathbf{J}$ Obes Relat Metab Disord. Dec.25(12):1823-33.

Hurson, M. \& Corish, C. 1997. Evaluation of lifestyle, food consumption and nutrient intake patterns among Irish teenagers. Ir J Med Sci. Oct-Dec.166(4):225-30.

Jellife, D.P. 1996. Assessment of the nutrition status of the community.WHO.

Kuczmarski, R.J., Ogden, C.L. \& GrummerStrawn, L.M. 2000. CDC growth charts: United States. Adv Data. 314:1-27.

National Center for Health Statistics. 2003. Prevalence of overweight among children and adolescents: United States, 1999-2000. Available at: www.cdc.gov/ nchs/products/pubs/pubd/hestats/ overwght99.htm.

National Research Council. 1989. Recommended Dietary Allowances. Washington DC: National Academy Press.

Nestle, M. 2002. Food Politics. How the Food Industry Influences Nutrition and Health. Berkeley, CA: University of California Press

Nutrition Institute. 1996. Food Composition Tables. Cairo. Egypt

Osman, N.A. 1997. A Study of the Consumption of Fast Food in the Age Group 1222 Years. Thesis, Master of Public Health (Nutrition). High Institute of Public Health, University of Alexandria, Alexandria, Egypt.

Pereira, M.A., Kartashov, A.I. \& Ebbeling, C.B. 2003. Fast food meal frequency and the incidence of obesity and abnormal glucose homeostasis in young black 
and white adults: the CARDIA study [abstract]. Circulation.107:35.

Rolls, B.A., Morris, E.L. \& Roe, L.S. 2002. Portion size of food affects energy intake in normal-weight and overweight men and women. Am J Clin Nutr. 76:1207-1213.

Shanthy, A., Bowman,B.A., Steven, L., Gortmaker,S.L., Cara, B., Ebbeling,C.B., Mark, A., Pereira,M.A., David, S. \& Ludwig, M.D. 2004. Effects of FastFood Consumption on Energy Intake and Diet Quality among Children in a National Household Survey. Pediatrics Vol. 113 No. 1 January.

St Onge,M.P., Keller, K.L. \& Heymsfield, S.B. 2003. Changes in childhood food consumption patterns: a cause for concern in light of increasing body weights. Am J Clin Nutr. 78:1068-1073.

Story, M., Neumark-Sztainer, S. \& French, S. 2002. Individual and environmental influences on adolescent eating behaviors. J Am Diet Assoc.102:540-551.
Subar, A.F., Krebs-Smith, S.M., Cook, A. \& Kahle, L.L. 1998. Dietary sources of nutrients among US Children, 1989-1991. Pediatrics.

US Department of Agriculture, Agricultural Research Service. 2000. The Continuing Survey of Food Intakes by Individuals and the Diet and Health Knowledge Survey, 1994-96 [on CD-ROM]. Beltsville, MD: US Department of Agriculture.

Wikipedia, the free encyclopedia. 2006. GNU free documentation license. Wikimedia Foundation, Inc.

World Health Organization (WHO) 1995. Physical Status. The use and interpretation of Anthropometry. Report of a WHO Expert Committee. WHO Technical Report Series. 854:263-311.

Zive, M.M., Elder, J.P. \& Prochaska, J.J. 2002. Sources of dietary fat in middle schools. Prev Med. 35:376-382.

\section{الثمود على استهالوك الأغذية السريعة:

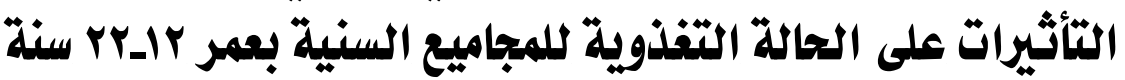 \\ ماجةمحمشباليك -سناء إبرالهيم صالح قمم الغنية - المعل المركزي للأغنية ولأعلاف -مركز الجحث الزراعية - الإسكنرية}

انتثر لستهلاك الثبب للأغذية للسريعة انتشاراسريعا خلل اللسنوات الأخيرة وشجعت جانبية الأصنف المختلفة

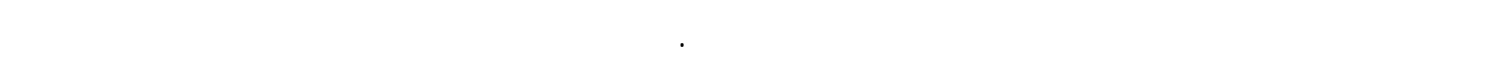

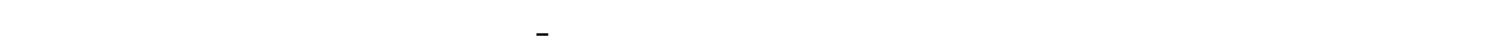

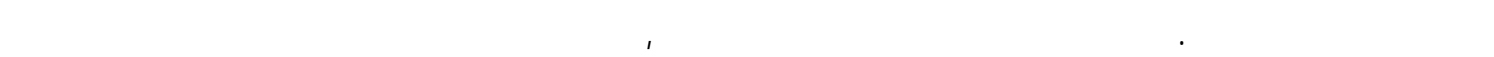

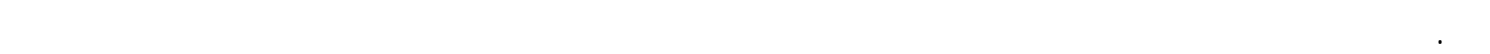

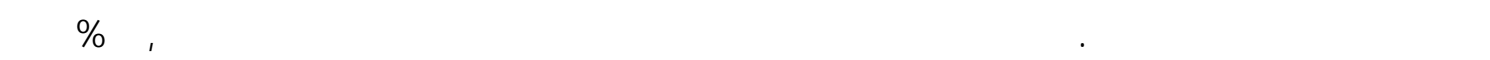

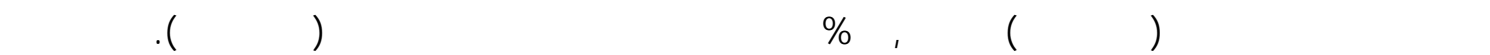

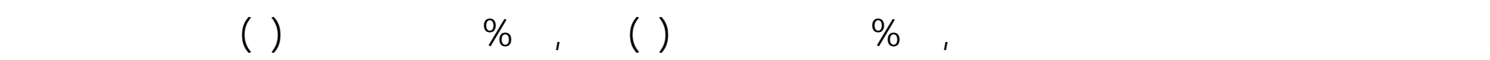

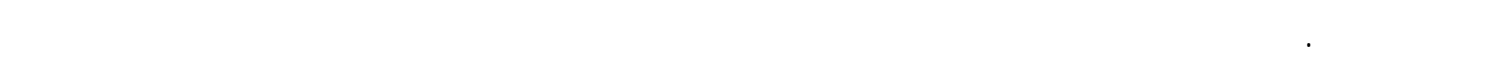

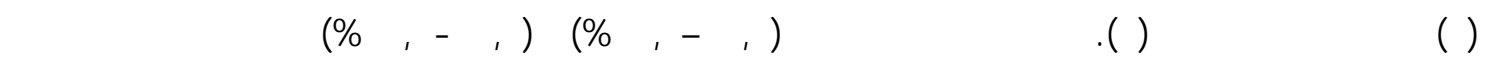

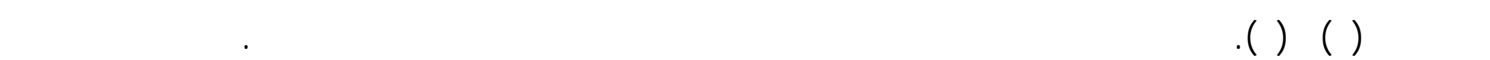

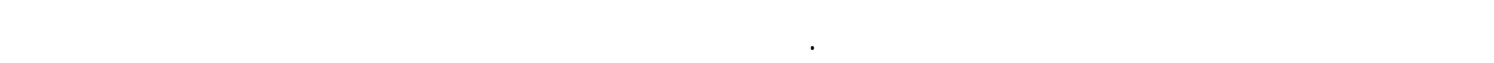

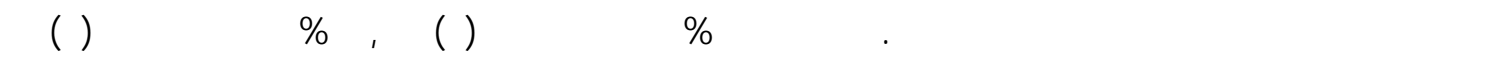

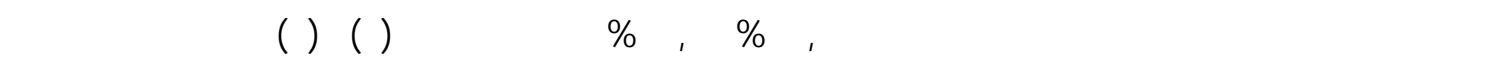

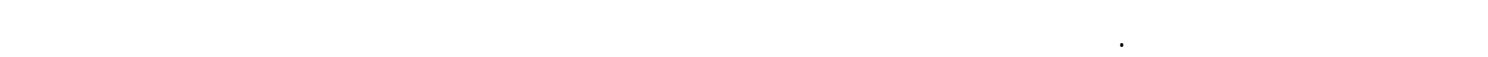

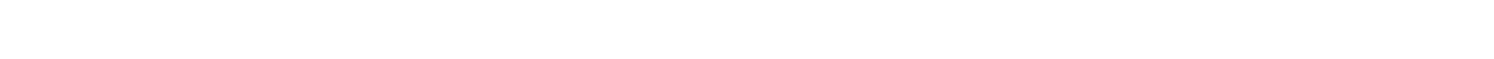

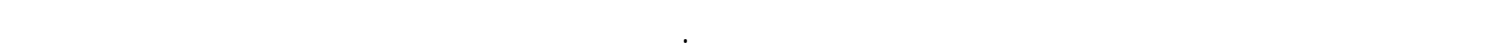

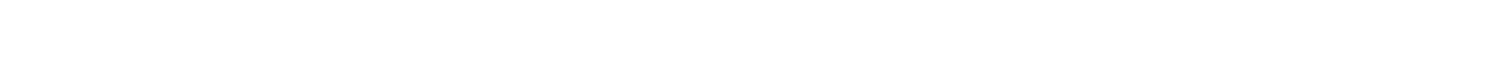
منع ببع الأغنية اللسريعة في المداس. لمسابل. 